\title{
ROLE OF KNOWLEDGE MANAGEMENT PROCESSES IN IMPROVING QUALITY OF EDUCATIONAL SERVICES “APPLIED STUDY OF SAMPLE VIEWS FROM FACULTY MEMBERS IN A NUMBER OF FACULTIES OF THE UNIVERSITY OF THI-QAR"
}

\author{
Firas Adnan Abbas ALTabtabae* and Faisal Ghazi Yusuf \\ Department of Business Administrations, Faculty of Administration \& Economics, \\ University of AL-Qadisiyah, Al-Diwaniyah-Iraq. \\ *Corresponding Author Email: firas.a.abbas@qu.edu.iq, faisalgazi75@gmail.com
}

\begin{abstract}
This study discussed the knowledge management processes of acquisition, storage, transfer and application of knowledge in one of Iraqi universities, University of ThiQar, Where token a sample Consisting of (120) Teaching for different levels of (6) faculties, which represents research community, the relationship and impact of these processes on the quality and educational services were analyzed and their dimensions (tangibility, Reliability, Response, guarantee and empathy), Provided by these colleges, The analysis of the data that resulted from the questionnaire, Number of her questions (41) question, showed that there was a correlation and impact between the two variables. The sample was concerned with the documentation of knowledge which is describe by excellence in performance and application of ideas in practice and is concerned with the good appearance and provide good service, despite its lack of knowledge of steps to simplify important methods In the provision of educational services, which, although presented but still need to develop the modernization of the methods used.
\end{abstract}

Keywords: Knowledge management, knowledge management processes, quality, quality of educational services

Cite this Article: Firas Adnan Abbas ALTabtabae and Faisal Ghazi Yusuf, Role of Knowledge Management Processes in Improving Quality of Educational Services "Applied Study of Sample Views from Faculty Members in a Number of Faculties of the University of Thi-Qar", International Journal of Management, 10 (5), 2019, pp. $115-127$.

http://iaeme.com/Home/issue/IJM?Volume=10\&Issue $=5$ 


\section{INTRODUCTION}

Knowledge is an important aspect in shaping the future of organizations, through which various institutions and in various public and private areas, even in the daily lives of individuals, can achieve creativity in daily activities, where modern organizations aspire to acquire knowledge of the two sections explicitly found in the instructions and publications Which can be accessed by different individuals at any time, as well as the implication of the number of individuals in their minds is obtained through creativity and innovation and the employment of holders of this type of knowledge as it represents an important part of modern organizations, especially as Knowledge of knowledge, especially with regard to universities and institutes that provide good and distinct educational services contribute to the expectations and desires of the beneficiaries of the service. Knowledge is seen as one of the essential elements in the process of creativity, innovation and excellence in educational organizations through effective management. Quality in education has generally been defined as the standards that must be met in order to achieve established objectives. At the same time, quality assurance in education refers to achieving a set of goals. A good education is a set of features of the course and its attributes that meet the expectations of the beneficiaries.

\section{STUDY METHODOLOGY}

1- Study Problem: This study attempts to identify the reality of knowledge management in some faculties of the University of Thi-Qar and identify level the quality of educational services, and the study is being dealt with the problem by answering the following two main questions:

What is the reality of the application of knowledge management processes at the University of Thi-Qar Searched Faculties?

What is the role application of knowledge management processes in improving the quality of educational services in Searched faculties?

2- Study Questions: This study seeks to answer following main questions:

What is the reality of knowledge management processes in the Faculties of study at the University of Thi-Qar (knowledge acquiring, knowledge storing, knowledge transfer, knowledge applying)?

What is the level of quality of educational services in each faculty of the university faculties studied?

What are the obstacles that prevent the application of knowledge management in faculties studied?

3- Study Importance: The importance of this study is that it deals with a modern administrative subject that has become the core of the work of the University of Thi-Qar $।$ Faculties throughout the study. This university works in an environment characterized by development, change and Renewal, Knowledge management is one of the basic means that enable these universities to reach the stage of excellence in achieving their objectives, This study aims to contribute to the put of mechanisms to develop and activate knowledge management at the university to improve the quality of its services.

4- Study Objectives: This study aims to achieve following objectives:

1.Identifying the reality of knowledge management at the University of Thi-Qar (Faculties studied) this is done by monitoring the reality of the application of the core processes of knowledge management from knowledge acquiring, knowledge storing, knowledge transfer and knowledge applying in Faculties of study. 
2.Identifying the level of quality of educational services in the University of Thi-Qar (Faculties studied).

3.Analysis of the relationship between the reality of knowledge management and the quality of educational services in the faculties.

5- Hypotheses of Study: This study seeks to examine (test) following hypotheses:

H1: There is a significant relationship between the reality of the knowledge acquisition and the quality of educational services Thi-Qar University $\backslash$ studded Faculties.

H2: $_{2}$ There is a significant relationship between the reality of the Knowledge storage and the quality of educational services Thi-Qar University $\backslash$ studded Faculties.

H3: There is a significant relationship between the reality of the knowledge transfer and the quality of educational services Thi-Qar University $\backslash$ studded Faculties.

H4: There is a significant relationship between the reality of the Application of knowledge and the quality of educational services Thi-Qar University $\backslash$ studded Faculties.

H5: There is an impact of knowledge management processes (Acquisition, storage, transportation, application) to the quality of educational services.

6- Boundaries of Study: Time Boundaries- This study was carried out in 2019.

Spatial Boundaries: This study was carried at the University of Thi-Qar \ studded Faculties.

Objectivity Boundaries: This study was limited to the study of two basic variables: The first variable is knowledge management processes (which include a core set of knowledge management functions: knowledge acquisition, knowledge storage, knowledge transfer, knowledge application. The second variable is the quality of educational services, which includes the following dimensions (tangible, reliability, responsiveness, security, empathy).

7- Study Tool: The questionnaire was used as a main data collection tool. This questionnaire was designed in light of the review of the relevant literature as well as a collection of Arabic and foreign books, periodicals and research.

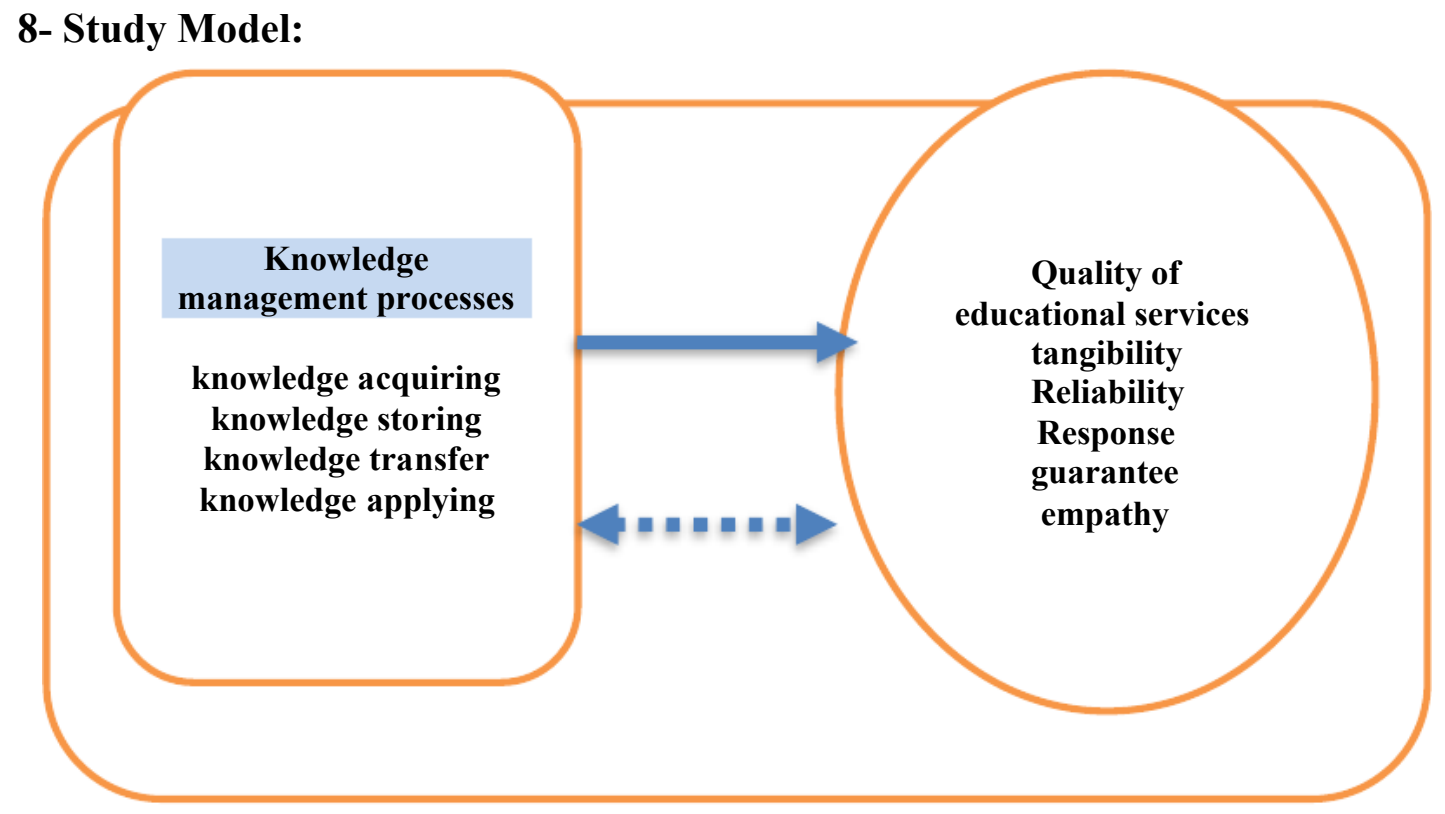

Figure 1 Eighth: Study Model 
9- The Approach Used in the Study: Was done in this study use descriptive approach to study the relationship between knowledge management and the quality of educational services at Thi-Qar University $\backslash$ studded Faculties, due to their relevance to this study.

10- Study Society: The community of this study consists of the teaching staff of the faculties at the University of Thi-Qar, the number of these Faculties (6), Faculty and the number of teaching (438).

\section{1- Study Sample:}

Table 1 A sample was selected for this study included (120) teaching.

\begin{tabular}{|c|l|c|c|}
\hline No & \multicolumn{1}{|c|}{ Faculty } & Number of respondents & Number of teaching in Faculty \\
\hline 1 & Law & 10 & 38 \\
\hline 2 & $\begin{array}{l}\text { Education for } \\
\text { Pure Sciences }\end{array}$ & 22 & 76 \\
\hline 3 & Engineering & 20 & 66 \\
\hline 4 & Science & 25 & 81 \\
\hline 5 & $\begin{array}{l}\text { Education for } \\
\text { Human } \\
\text { Sciences }\end{array}$ & 20 & 84 \\
\hline 6 & Arts & & 93 \\
\hline & Total Study Society (438) & Required sample (120) \\
\hline
\end{tabular}

Source: prepared by the researcher according to the questionnaire

12- Statistical Treatment: After unloading the answers of the sample (see Table (1)), the data were coded and data was entered using the computer (see study model Figure (1)), the data were then processed statistically using the Spss program, the statistical treatments used: repetitions, arithmetic averages and standard deviation, Pearson correlation coefficient derived from the statistical package (Spss.V.24), and the regression coefficient which from the statistical package (Amos.V.24).

\section{THEORETICAL SIDE}

\section{1- Knowledge management processes:}

\section{Philosophy of knowledge management processes:}

Knowledge has a wide and comprehensive concept for all that is new and different that distinguishes the organization from others and gives it support in its competitive position and improves its performance. As well the new type of capital based on ideas and experiences in a modern economy known as knowledge economy. Pointed out (Barley et al., $2018: 6$ ) That some combine knowledge with information with the basic distinction between them knowledge only in the minds of individuals and know it is a "correct doctrine justified", and explain the concept of knowledge as the experience, understanding and intuition arising from information and facts that can be shared, Participation it and communicated. Reached (Friedrich, 2017: 114) the social and material dimensions of knowledge are critical to understanding the transmission of knowledge from generation to generation. Where we identify the community structures that govern their production, dissemination and dependence on the knowledge economy of a society.

Knowledge Types: can be divided the Knowledge into implicit and explicit knowledge. Implicit knowledge in the individual mind, it is difficult to express them. The explicit knowledge in the documents, books, and instructions can be expressed and its knowledge is easier than implicit (Sensuse \& Cahyaningsih, 2018:71), and added (Koskinen, 2013:82) Other types of knowledge in addition to (explicit and implicit) as we see in the below: 
1. Productivity Knowledge. 3. Management knowledge.

2. Community knowledge. 4. Community knowledge.

\section{Knowledge management concept}

Knowledge management performance focuses on the implementation of effective knowledge management, and is distinct from organizational performance but related to it. The level of knowledge management implementation and the level of individual and organizational efforts in implementing knowledge management processes are part of the knowledge management performance (Zaim et al.,2018:2). A set of concepts for the management of knowledge, including:

- defined (Raudeliūnienè et al., 2018:544) The targeted and systematic management of processes, methods and tools, taking full advantage of the organization's knowledge potential to achieve strategic goals, effective decision-making, implementation and value creation.

- Signal (Kordab et al., 2018:142) it is a systematic process to obtain Staff knowledge, its organization and transfer, to be useful to other staff in the same organization. Managers should find the available knowledge sources within the organization and how staff can contribute to a knowledge management strategy where employees are considered to be senders of knowledge.

- Knowledge management is the systematic management of knowledge assets in an organization to create value and meet tactical and strategic requirements, It consists of practices, processes, strategies and systems that support and promote storage, assessment, participation, refinement and knowledge creation (Nguyen 2018:4).

\section{Knowledge management processes}

The fundamental task of knowledge management through its core processes and its subprocesses Is the pursuit to get on knowledge and Documented, used and applied, and provides the right knowledge at the right time for right person and at a lower cost. So it accomplishes its work efficiently and effectively through its operations which it is known as:

- Refers to the systematic coordination of knowledge management effectively, such as knowledge creation, exchange, storage and application (Santoro et al., 2017:2).

- indicated (Abu Gelh, 2016: 47) that it is essentially the fundamental processes of knowledge management, namely the knowledge generation, knowledge distribution, knowledge dissemination, knowledge application, It relies on the set of necessary methods, tools, structures and initiatives undertaken by organizations through the management and organization of their knowledge, in processes that add organizational value, In order to gain a competitive advantage over other competitors.

It is a sequential and systematic processes the purpose of seeking to acquire appropriate knowledge and stored by modern means of which ensure the dissemination and distribution among workers at all levels and assist in the use and application of these processes include the following dimensions:

Knowledge acquisition: The acquisition of knowledge is known as the process of developing and creating of insight, skill and relationships to get knowledge, there must be a willingness and ability to acquire knowledge that is crucial during the acquisition process (Afqarina, 2018:16-19).

Knowledge storage: Storage process in the regulatory warehouses For keep and other multiple uses and applying a number of retrieval tools and techniques that store and retrieve organizational knowledge refers to management memory which includes knowledge in many 
Role of Knowledge Management Processes in Improving Quality of Educational Services "Applied Study of Sample Views from Faculty Members in a Number of Faculties of the University of Thi-Qar"

forms such as written records, documented administrative policies and procedures, structured knowledge stored in a database, data warehouse, or other business intelligence tools (Sirorei, 2019:3).

Knowledge transfer: Sees (Koohang, 2017: 32) The transfer of knowledge is the process of communicating it to the right person at the right time and appropriate form at the lowest cost and using technological tools and by individuals with knowledge themselves to increase the expertise and skills of other employees benefiting from the transfer individually or collectively.

Knowledge application: The actual use of knowledge captured or created and placed in the knowledge management cycle and its practical use. Reuse them in business strategy decisionmaking, task execution, service delivery, organizational performance and effectiveness (Obeidat et al., 2018:2).

\section{2 - Quality of educational services}

Educational services are from the most important services Marketed by institutions that are concerned with education and make them occupy a distinct market position and depending on the level of quality of these services, In addition, the importance of education sector and university education in particular and its progress and excellence refers to the progress and development of countries. And Confirms (Oakland, 2014:74) quality begins with understanding customer needs and ends when these needs are met. Quality is often used to indicate that "excellence" of a product or service can be used to signal that a piece of material or equipment corresponds to certain characteristics and physical dimensions often specified in the form of specifications. and it is used the main dimensions of the quality of education services So that the quality of services refers to the matching service for use or match them to the needs and desires of the beneficiaries or continuous improvement of these services is no secret to insiders difficulty of measuring the quality of services to what is characteristic of the specifications that are different from material goods. Most customers do not want to feel a unified service with all possible expectations, they want to feel that the product or service will be designed specifically for them so that they can see their wishes and needs heard (Vargina, 2019:10), and the quality of educational service by (Ismail \& Yahya, 2018: 182). It suited what customers can expect from the educational service with the actual awareness of the service provided, so Good service from the point of view of the beneficiaries of the customers are consistent and match their expectations. The quality of output in the form of enlightened students coming out of the system. In fact, all that permeates all aspects of academic life, and defined (Mohammed et al., 2018: 13), quality of educational services as standards and characteristics available in the elements of the educational process, whether inputs or outputs that meet the needs and desires of learners and society and the use of human and material elements efficiently and effectively in education. and indicate (Siamian et al., 2017: 3) To provide students with educational services inside and outside the institution in line with the standards of educational services to their satisfaction in the standard of educational services "taking into account the importance of providing the optimum minimum of materials more with satisfaction, where many of the specifications of these standards described as sympathy, location, protection, equality and satisfaction, and has been defined (Cheng, 2017: 7) However, they mean conformity to purpose and value for money. These two concepts are clearly linked to the quality of input and accountability of academics and higher education institutions.

A model was used (SERVQUAL) It included five dimensions of the quality of educational services, Some writers cited ten dimensions as follows (Reliability, Response, Efficiency, Arrivals, Gentleness, tangibility, Understanding, Safety, Credibility, communications) (Parasuraman et al., 1985 :47). But here we will focus on the five dimensions (Moosavi et al., 2017:488) Which includes the following: 
- Tangibility means the physical appearance of the elements, facilities, procedures, equipment and appearance of individuals.

- Reliability means the ability to deliver the service with the promised reliability and accuracy.

- Response / desire to help the consumer and provide service immediately.

- Guarantee / eligibility and fitness for employees and their ability to gain trust and credit.

- Empathy / attention and personal attention that the organization gives to its consumers.

This model is based on the system and the gaps measured by the degree of difference and direction between what is perceived by the consumer and what they expect consumer, The level of expectations for services quality in academic and educational environments due to a special case is at the highest level, Thus setting expectations and pay attention to the gap between the services provided and meet the expectations in such environments are important in educational organizations, Students and teachers are key customers and at the same time, their views can play an important role in improving service quality (Moosavi et al.,2017:488).

\section{SIDE APPLIED TO STUDY}

1 - Coding and characterization of the study axes: After classifying the data, it is entered into the statistical programs in which the required results are extracted, which in turn led to the use of programs (Spss.V.24, Amos.V.24). Therefore, the variables of the study were expressed by a set of symbols that facilitate the process of statistical analysis of the researcher and extract the results very precisely. Therefore, Table (2) illustrates this:

Table 2 Encoding the characterization of the study axes

\begin{tabular}{|l|l|c|c|}
\hline \multicolumn{1}{|c|}{ Axis } & \multicolumn{1}{|c|}{ Dimensions } & No & Symbol \\
\hline \multirow{3}{*}{$\begin{array}{l}\text { Knowledge } \\
\text { Management Processes }\end{array}$} & knowledge Acquisition & 6 & KMAC \\
\cline { 2 - 4 } & Knowledge storage & 5 & KMKS \\
\cline { 2 - 4 } & knowledge transfer & 5 & KMKT \\
\cline { 2 - 4 } & Knowledge application & 5 & KMAP \\
\hline \multirow{3}{*}{$\begin{array}{l}\text { Educational Services } \\
\text { Quality }\end{array}$} & Tangibility & 4 & QETA \\
\cline { 2 - 4 } & Reliability & 4 & QERE \\
\cline { 2 - 4 } & Response & 4 & QERS \\
\cline { 2 - 4 } & Guarantee & 3 & QESE \\
\cline { 2 - 4 } & Empathy & 5 & QESY \\
\hline
\end{tabular}

2 - Test the normal distribution of the study: The natural distribution test is an important consideration for the study before conducting the analysis and extracting the results, Thus, the test (Kolmogorov-Smirnov, Shapiro-Wilk) Two of the most famous tests involved in extracting the normal distribution of variables and dimensions of the study, Which indicates that the moral value if it is higher than (0.05) We can accept the results of the study up, Which indicates that the moral value if less than (0.05) The results of the study are neglected, and table (3) shows the results of the normal distribution of the study variables.

Table 3 Normal distribution test results

\begin{tabular}{|l|c|c|c|c|c|c|}
\hline \multicolumn{7}{|c|}{ Tests of Normality } \\
\hline & \multicolumn{3}{|c|}{ Kolmogorov-Smirnov } & \multicolumn{3}{c|}{ Shapiro-Wilk } \\
\cline { 2 - 7 } & Statistic & df & Sig. & Statistic & df & Sig. \\
\hline KMAC & .141 & 120 & $0.05>\mathrm{P}$ & .891 & 120 & $0.05>\mathrm{P}$ \\
\hline KMKS & .148 & 120 & $0.05>\mathrm{P}$ & .893 & 120 & $0.05>\mathrm{P}$ \\
\hline KMKT & .186 & 120 & $0.05>\mathrm{P}$ & .892 & 120 & $0.05>\mathrm{P}$ \\
\hline KMAP & .164 & 120 & $0.05>\mathrm{P}$ & .901 & 120 & $0.05>\mathrm{P}$ \\
\hline
\end{tabular}


Role of Knowledge Management Processes in Improving Quality of Educational Services "Applied Study of Sample Views from Faculty Members in a Number of Faculties of the University of Thi-Qar"

\begin{tabular}{|c|c|c|c|c|c|c|}
\hline KMPR & .136 & 120 & $0.05>\mathrm{P}$ & .903 & 120 & $0.05>\mathrm{P}$ \\
\hline QETA & .166 & 120 & $0.05>\mathrm{P}$ & .892 & 120 & $0.05>\mathrm{P}$ \\
\hline QERE & .153 & 120 & $0.05>\mathrm{P}$ & .876 & 120 & $0.05>\mathrm{P}$ \\
\hline QERS & .189 & 120 & $0.05>\mathrm{P}$ & .874 & 120 & $0.05>\mathrm{P}$ \\
\hline QESE & .234 & 120 & $0.05>\mathrm{P}$ & .818 & 120 & $0.05>\mathrm{P}$ \\
\hline QESY & .173 & 120 & $0.05>\mathrm{P}$ & .868 & 120 & $0.05>\mathrm{P}$ \\
\hline QESER & .151 & 120 & $0.05>\mathrm{P}$ & .886 & 120 & $0.05>\mathrm{P}$ \\
\hline
\end{tabular}

The results of Table (3) indicate that the moral value is higher than $(0.05)$, which means that the data drawn from the population of the study sample follow the normal distribution.

3 - Test the validity and reliability of measurement tool: This paragraph is one of the most important paragraphs that show the reliability and consistency of dimensions and variables of the study, as in order to measure this, the test was used Kronbach Alpha coefficient, which assumes that the proportion of stability and credibility should be higher than (0.75) So we can release a measurement tool that has consistency, reliability, and table (4) Kronbach Alpha coefficient shows the axes of the study and the dimensions of each axis.

Table 4 Kronbach Alpha coefficient

\begin{tabular}{|l|c|l|c|c|}
\hline \multicolumn{1}{|c|}{ Axis } & $\begin{array}{c}\text { Cronbach Alpha for } \\
\text { Variables }\end{array}$ & \multicolumn{1}{|c|}{ Dimensions } & No & $\begin{array}{c}\text { Cronbach Alpha for } \\
\text { dimensions }\end{array}$ \\
\hline \multirow{3}{*}{$\begin{array}{l}\text { Knowledge } \\
\text { management } \\
\text { processes }\end{array}$} & \multirow{3}{*}{$\mathbf{. 9 9 8}$} & $\begin{array}{l}\text { knowledge } \\
\text { Acquisition }\end{array}$ & 6 & .998 \\
\cline { 3 - 5 } & & Knowledge storage & 5 & .998 \\
\cline { 3 - 5 } & knowledge transfer & 5 & .998 \\
\cline { 3 - 5 } & & $\begin{array}{l}\text { Knowledge } \\
\text { application }\end{array}$ & 5 & .998 \\
\hline \multirow{2}{*}{$\begin{array}{l}\text { educational } \\
\text { services } \\
\text { Quality }\end{array}$} & tangibility & 4 & .998 \\
\cline { 3 - 5 } & Reliability & 4 & .998 \\
\cline { 3 - 5 } & \multirow{2}{*998}{} & Response & 4 & .998 \\
\cline { 3 - 5 } & Guarantee & 3 & .998 \\
\cline { 3 - 5 } & Empathy & 5 & .998 \\
\hline
\end{tabular}

We can see from the results in Table (4) that the Kronbach alpha coefficients are all higher than $75 \%$, which means that the Questionnaire is stable.

\section{4 - Descriptive statistics for data}

Knowledge management processes: The results of table (5) show that the general average of the arithmetic media for knowledge management processes was (3.84) with standard deviation equal to (1.058). What contributed to this is the knowledge transfer dimension of (KMKT) with an arithmetic mean of (3.75) with a standard deviation of (0.999), while the knowledge acquisition dimension of (KMAC) was ranked second with a mean of (3.85) and a standard deviation of (1.068). While the third rank from the share of the knowledge storage dimension of (KMKS) with an arithmetic mean of (3.84) and a standard deviation of (1.078), while the last rank was within the dimension of knowledge application of (KMAP) with an arithmetic mean of (3.75) and standard deviation of (1.107). This means that the sample studied has a wide awareness of the importance of incorporating knowledge into its internal processes In order to conduct its functions and addressing threats and investment opportunities and to address weaknesses afflicting. Therefore, the studied sample should apply knowledge which are acquired after extensive studies on their suitability to the environment of the organization. 
Firas Adnan Abbas ALTabtabae and Faisal Ghazi Yusuf

Table 5 Descriptive analysis of paragraphs of knowledge management processes

\begin{tabular}{|c|c|c|c|c|c|c|c|}
\hline $\begin{array}{c}\text { importanc } \\
\text { e order }\end{array}$ & $\begin{array}{c}\text { standard } \\
\text { deviatio } \\
\mathbf{n}\end{array}$ & $\begin{array}{c}\text { Arithmeti } \\
\mathbf{c} \text { mean }\end{array}$ & No & $\begin{array}{c}\text { importanc } \\
\mathbf{e} \text { order }\end{array}$ & $\begin{array}{c}\text { standard } \\
\text { deviatio } \\
\mathbf{n}\end{array}$ & $\begin{array}{c}\text { Arithmeti } \\
\mathbf{c} \text { mean }\end{array}$ & No \\
\hline 3 & 1.097 & 3.88 & $\begin{array}{c}\text { KMKT } \\
1\end{array}$ & 1 & 0.943 & 4.13 & $\begin{array}{c}\text { KMAC } \\
1\end{array}$ \\
\hline 1 & 0.925 & 4.13 & $\begin{array}{c}\text { KMKT } \\
2\end{array}$ & 6 & 1.296 & 3.49 & $\begin{array}{c}\text { KMAC } \\
2\end{array}$ \\
\hline 4 & 1.077 & 3.82 & $\begin{array}{c}\text { KMKT } \\
3\end{array}$ & 4 & 1.118 & 3.83 & $\begin{array}{c}\text { KMAC } \\
3\end{array}$ \\
\hline 2 & 0.874 & 4.01 & $\begin{array}{c}\text { KMKT } \\
4\end{array}$ & 3 & 1.13 & 3.91 & $\begin{array}{c}\text { KMAC } \\
4\end{array}$ \\
\hline 5 & 1.154 & 3.75 & $\begin{array}{c}\text { KMKT } \\
5\end{array}$ & 5 & 1.195 & 3.63 & $\begin{array}{c}\text { KMAC } \\
5\end{array}$ \\
\hline first & 0.999 & 3.92 & KMKT & 2 & 0.935 & 4.09 & $\begin{array}{c}\text { KMAC } \\
6\end{array}$ \\
\hline 3 & 1.134 & 3.78 & $\begin{array}{c}\text { KMAP } \\
1\end{array}$ & second & 1.068 & 3.85 & KMAC \\
\hline 1 & 0.996 & 3.91 & $\begin{array}{c}\text { KMAP } \\
2\end{array}$ & 2 & 1.256 & 3.95 & KMKS1 \\
\hline 2 & 1.056 & 3.86 & $\begin{array}{c}\text { KMAP } \\
3\end{array}$ & 4 & 1.206 & 3.58 & KMKS2 \\
\hline 5 & 1.288 & 3.57 & $\begin{array}{c}\text { KMAP } \\
4\end{array}$ & 3 & 1.128 & 3.73 & KMKS3 \\
\hline 4 & 1.172 & 3.64 & $\begin{array}{c}\text { KMAP } \\
5\end{array}$ & 2 & 0.977 & 3.95 & KMKS4 \\
\hline fourth & 1.107 & 3.75 & KMAP & 1 & 0.999 & 3.96 & KMKS5 \\
\hline$* * * * *$ & 1.058 & 3.84 & KMPR & third & 1.078 & 3.84 & KMKS \\
\hline
\end{tabular}

Educational Services Quality: We can see from the results in Table (6) that the average arithmetic mean of the quality of educational services has reached (3.97) with a arithmetic mean of (0.999). And a standard deviation of (0.909), While the second place of the share of empathy dimension of (QESY) with an arithmetic mean of (4.05) and standard deviation equal to (0.955), and the response dimension of (QERS) ranked third with an arithmetic mean of (3.92) and standard deviation of (1.019), the fourth dimension of the share of the reliability dimension of (QERE) was an arithmetic mean of (3.90) and a standard deviation of (1.072), came after tangibility and private (QETA) last rank with a mean of (3.79) and a standard deviation was (1.096), It is possible to say that the study sample is concerned with the need to maintain the quality of educational services by promoting a spirit of compassion and dedication to work, which must respond to the requirements of the environment and adapt to them in order to keep pace with developments that occur abroad. 
Role of Knowledge Management Processes in Improving Quality of Educational Services "Applied Study of Sample Views from Faculty Members in a Number of Faculties of the University of Thi-Qar"

Table 6 Descriptive analysis of the paragraphs of educational services quality

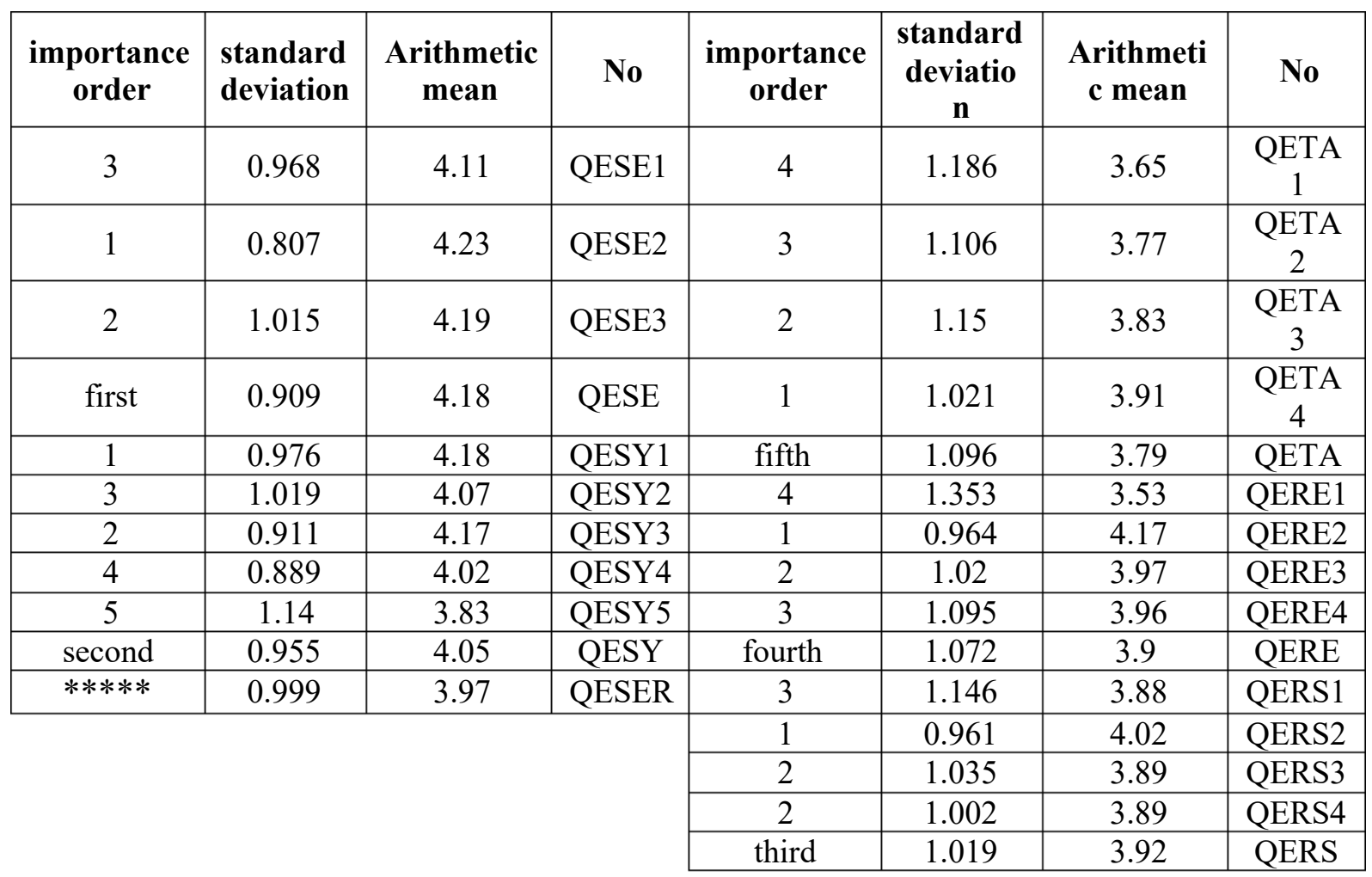

5 - Measure the correlation relationship between the variables of the study: This section is concerned with measuring the correlation relationship between the variables and dimensions of the study, which refers to the variable of knowledge management processes as an independent variable, and the quality of educational services as a dependent variable.

Table 7 Correlation relationship matrix

\begin{tabular}{|l|l|c|c|c|c|c|}
\hline \multicolumn{2}{|c|}{} & KMAC & KMKS & KMKT & KMAP & KMPR \\
\hline \multirow{3}{*}{ QETA } & Pearson Correlation & $.982^{* *}$ & $.985^{* *}$ & $.988^{* *}$ & $.994^{* *}$ & $.992^{* *}$ \\
\cline { 2 - 7 } & Sig. (2-tailed) & .000 & .000 & .000 & .000 & .000 \\
\cline { 2 - 7 } & $\mathrm{N}$ & 120 & 120 & 120 & 120 & 120 \\
\hline \multirow{3}{*}{ QERE } & Pearson Correlation & $.991^{* *}$ & $.990^{* *}$ & $.983^{* *}$ & $.980^{* *}$ & $.991^{* *}$ \\
\cline { 2 - 7 } & Sig. (2-tailed) & .000 & .000 & .000 & .000 & .000 \\
\cline { 2 - 7 } & $\mathrm{N}$ & 120 & 120 & 120 & 120 & 120 \\
\hline \multirow{3}{*}{ QERS } & Pearson Correlation & $.979^{* *}$ & $.985^{* *}$ & $.987^{* *}$ & $.982^{* *}$ & $.988^{* *}$ \\
\cline { 2 - 7 } & Sig. (2-tailed) & .000 & .000 & .000 & .000 & .000 \\
\cline { 2 - 7 } & $\mathrm{N}$ & 120 & 120 & 120 & 120 & 120 \\
\hline \multirow{3}{*}{ QESE } & Pearson Correlation & $.968^{* *}$ & $.960^{* *}$ & $.950^{* *}$ & $.936^{* *}$ & $.958^{* *}$ \\
\cline { 2 - 7 } & Sig. (2-tailed) & .000 & .000 & .000 & .000 & .000 \\
\cline { 2 - 7 } & $\mathrm{N}$ & 120 & 120 & 120 & 120 & 120 \\
\hline \multirow{3}{*}{ QESER } & Pearson Correlation & $.988^{* *}$ & $.988^{* *}$ & $.981^{* *}$ & $.972^{* *}$ & $.987^{* *}$ \\
\cline { 2 - 7 } & Sig. (2-tailed) & .000 & .000 & .000 & .000 & .000 \\
\cline { 2 - 7 } & $\mathrm{N}$ & 120 & 120 & 120 & 120 & 120 \\
\cline { 2 - 7 } & Pearson Correlation & $.992^{* *}$ & $.992^{* *}$ & $.989^{* *}$ & $.984^{* *}$ & $.994^{* *}$ \\
\cline { 2 - 7 } & Sig. (2-tailed) & .000 & .000 & .000 & .000 & .000 \\
\cline { 2 - 7 } & $\mathrm{N}$ & 120 & 120 & 120 & 120 & 120 \\
\hline
\end{tabular}

The results in Table (7) indicate that there is a statistically significant correlation relationship between the knowledge management processes and the quality of educational 
services, and the dimensions of each. The correlation between variables and dimensions of the study ranged from (0.936) minimum to (0.994) maximum.

6 - Measuring the effect relationship between the variables: The results of Table (7) shown in Figure (2) indicate that there is an impact of knowledge management processes on the quality of educational services, which generates a set of important material points, which can be reversed in the following:

- There is statistically significant effect on the dimension of knowledge acquisition in the quality of educational services, where the value of the impact (0.389) standard error of (0.071), a critical value equal to (5.479).

- There is statistically significant effect of the dimension of knowledge storage in the quality of educational services, as the impact value of a direct value of (0.372) standard error of (0.083), a critical value equal to (4.482).

- There is the presence of a statistically significant effect of the knowledge transfer dimension in the quality of educational services, where the value of the impact $(0.415)$ with a standard error of (0.052), a critical value equal to (7.981).

- There is a statistically significant effect on the dimension of applying knowledge in the quality of educational services, as the value of the inverse effect of (0.176) standard error effect amounted to (0.059), a critical value of (2.98 -).

- The explanatory value of the effect of variable knowledge management processes on the quality of educational services amounted to (0.992), which means that knowledge management processes have interpretation $(0.992)$ of the events that stand without preventing the development of quality educational services, while the value of the remaining amount of (0.008), they fall outside the study limits.

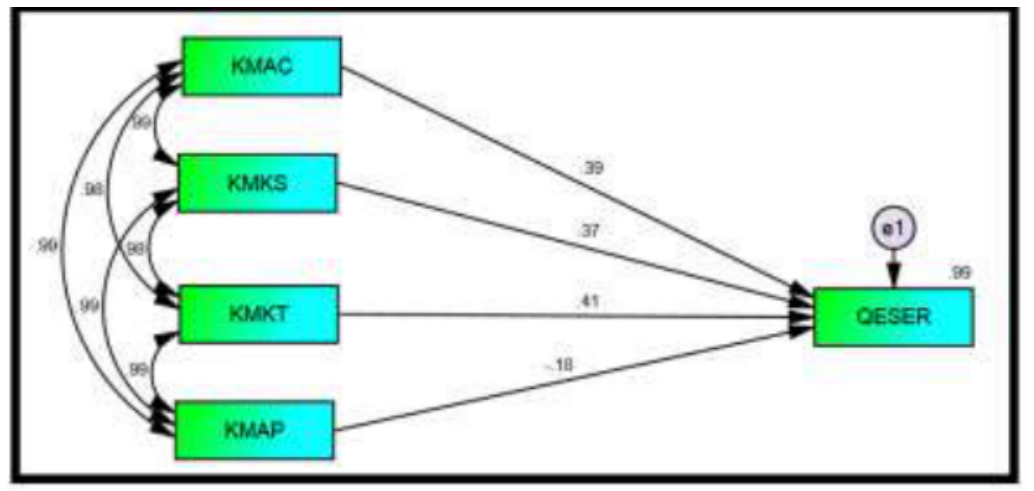

Figure 2: Direct impact of the dimensions of knowledge management processes on the quality of educational services

Table (8) shows the standard weights for the direct impact of the dimensions of knowledge management processes on the quality of educational services.

Table 8 Standard weights for the direct impact of the dimensions of knowledge management processes on the quality of educational services

\begin{tabular}{|l|l|l|l|l|l|l|}
\hline & & & Estimate & S.E. & C.R. & P \\
\hline QESER & $<---$ & KMAC & .389 & .071 & 5.479 & $* * *$ \\
\hline QESER & $<---$ & KMKS & .372 & .083 & 4.482 & $* * *$ \\
\hline QESER & $<---$ & KMKT & .415 & .052 & 7.981 & $* * *$ \\
\hline QESER & $<---$ & KMAP & -.176 & .059 & -2.98 & $* * *$ \\
\hline
\end{tabular}




\section{CONCLUSIONS}

- There is a positive statistical correlation between knowledge management processes and the quality of educational services and the dimensions of each, which leads to the creation of good results between the knowledge processes in order to improve the quality of educational services provided, which should strengthen the principle of cooperation between teaching staff in order to remove unnecessary activities and raise the level of training.

- There is a significant statistical impact relationship to the dimensions of knowledge management processes in the quality of educational services, which leads to increased knowledge of the study sample studied and applied knowledge management processes of (knowledge acquisition, knowledge storage, knowledge transfer and knowledge application).

- The sample has distinguished and trained cadres documenting its knowledge of pamphlets and reports, and has an attractive appearance but lacks simplification of the steps through which educational services are provided.

\section{RECOMMENDATIONS}

- Provide extensive databases and repositories for the storage of important knowledge and archived by modern technologies and the development of buildings and material requirements on an ongoing basis

- Facilitate the process of exchange of ideas and cooperation between teachers attention to accurate teaching programs and encourage cooperation with students and accelerate the provision of services.

\section{REFERENCES}

[1] Abu Gelh, A. "The role of knowledge management in improving the quality of outputs of higher education institutions, 2013-2015." Sudan: repository.sustech.edu, Volume 1. No. 1,2016

[2] Ismail, S., Yahya A. "The role of the labor market in improving the quality of accounting education / survey of a sample of academics and professionals in accounting in Duhok," (Academic Journal of Nowruz University) 2, No. 7, 2018.

[3] Zaim, H., Muhammed S., Tarim M. "Relationship between knowledge management processes and performance: critical role of knowledge \& utilization in organizations," Knowledge Management Researc Practice, 2018.

[4] Vidhya Sivasailanathan, Prabhat Kumar, Dr. N. Manoharan and K. Lingeswaran, Alara Implementation and Knowledge Management in Nuclear Power Plants. International Journal of Advanced Research in Engineering and Technology, 6(8), 2015, pp. 69-82.

[5] Sensuse D., Cahyaningsih E."Knowledge Management Models: A Summative Review," International Journal of Information Systems in the Service Sector, Volume 10 • Issue 1 • January-March, 2018.

[6] Moosavi A., Mohammad M., Hajar Z., Saber A., Mahdi M., Aziz R. "The Quality of Educational Services from Students' Viewpoint in Iran: A Systematic Review and Metaanalysis," Iran J Public Health. ‘2017 Apr; 46: 447-455.

[7] Stephen I. Dugguh and Jane I. Terzungwe, "Knowledge Management and Employee Performance in the Brewery Industry: A Theoretical Examination of Consolidated Brewery Ltd, Makurdi-Nigeria", International Journal of Advanced Research in Management (IJARM), Volume 5, Issue 4, July- August (2014), pp. 48-59. 
[8] Oakland, J. "Total Quality Management and Operational Excellence," Fourth Edition. New York: Routledge is an imprint of the Taylor \& Francis Group, an informa business, 2014.

[9] Koskinen, K. "Knowledge Production in Organizations," Switzerland- Springer Publishing, 2013.

[10] Vargina, V. "How to Improve Hotel Service? Case: Leinon Apartments," Thesis report 2019: Saimaa University of Applied Sciences Tourism and Hospitality Imatra, 2019

[11] C. Ramanigopal. "Knowledge Management Strategies in Higher Education", International Journal of Advanced Research in Management (IJARM), Volume 3, Issue 1, January- June 2012.

[12] Barley, W., Treem, J., Kuhn, T. "Valuing Multiple Trajectories of Knowledge: A Critical Review and Agenda for Knowledge Management Research," (Academy of Management Annals, (24) 1, 2018.

[13] Santoro, G., Vrontis, D., Thrassou, A., \& Dezi, L, The Internet of Things: Building a knowledge management system for open innovation and knowledge management capacity. Technological Forecasting and Social Change. doi:10.1016/j.techfore.2017.02,2017

[14] Obeidat, B., Lama, H., Raed, M. "The Influence of Knowledge Management Uses on Total Quality Management Practices in Commercial Banks of Jordan." Modern Applied Science, (2018), pp 1-16.

[15] N. Sivagiri, The Effects of Knowledge Management Infrastructure Capability on Knowledge Management Effectiveness of Doctors: An Empirical Study Journal of Management, 5(5), 2018, pp. 218-231

[16] Nguyen, NgocBuuCat Data Mining in Knowledge Management Processes: Developing ", an Implementing Framework." Master Thesis, 30 hp. N SPM 2018.09. Umeå University, Faculty of Social Sciences: Department of informatics, 2018

[17] Parasuraman, A, Zeithaml, V., Berry, L. "A Conceptual Model of Service for Future Research Quality and Its I-implications." Journal of Marketing, Vol. 49, 1985, pp 41-50.

[18] Afqarina, R. "Pengaruh knowledge management Dan organizational learning terhadap kinerja organisasi melalui inovasi sebagai variabel intervening." Indonesia: Universitas Islam Indonesiafakultas Ekonomi \Yogyakarta, Vol. 1. No. 1, 2018.

[19] Kordab, M., Jurgita R."Knowledge management cycle: a scientificliterature review." 10th International Scientific Conference "Business and Management 2018". May 3-4, 2018, Vilnius, LITHUANIA: http://www.bm.vgtu.lt, 2018.

[20] Sirorei, E.C., Fombad, M.C. "Knowledge management processes at St Paul's University Library in Kenya', South African Journal of Information Management 21(1), (2019). https://doi. org/10.4102/sajim.v21i1.946

[21] Koohang, A., Paliszkiewicz, J., Goluchowski, J."The impact of leadership on trust, knowledge management, and organizational performance", Industrial Management \& Data Systems, Vol. 117 No. 3, (2017), pp. 521-537.

[22] Siamian, H., Rostami, F., Ghara, A. N., Abedi, G."The Students' Viewpoint on Quality of EducationalServicesinIran.Materiasocio-medica,29(1),(2017),pp48-51. doi:10.5455/msm.2017.29.48-51

[23] Cheng, M." Reclaiming quality in higher education: a human factor approach." Quality in HigherEducation,23:2, 2017, pp 153-167,https://doi.org/10.1080/13538322.2017.1358954. 